\title{
Motivasi Siswa Mengikuti Bimbingan Belajar
}

\author{
${ }^{1}$ Elfrida Khoerunnisa dan ${ }^{2}$ Gisella Arnis Grafiyana \\ Fakultas Psikologi, Universitas Muhammadiyah Purwokerto, \\ ${ }^{1}$ koerunnisaelfrida@yahoo.co.id, ${ }^{2}$ gisella.arnis@ump.ac.id
}

\begin{abstract}
Abstrak
Dewasa ini, banyak berkembangnya Bimbingan Belajar atau sering disingkat dengan nama BimBel. Tujuan dari siswa-siswi mengikuti BimbBel untuk mengembangkan dan merubah prestasi belajarnya ke arah yang lebih baik. Di sisi lain, ada sebagian besar siswa yang berusaha untuk mengembangkan dan merubah prestasinya tanpa mengikuti BimBel. Penelitian ini dilakukan untuk mengetahui motivasi dan tujuan siswa-siswi generasi Millenial ini untuk mengikuti maupun tidak mengikuti BimBel, kemauan untuk belajar mandiri, dan sejauh mana orang tua berperan menjadi motivasi siswa-siswi tersebut. Penelitian ini menggunakan metode kuantitatif dengan teknik pengumpulan data melalui pengisian survei terbuka dengan menggunakan google form maupun pengisian langsung. Responden terdiri dari remaja yang berusia 17 tahun dengan jumlah 12 orang. Hasil penelitian menunjukkan bahwa secara keseluruhan, motivasi siswa untuk mengikuti BimBel yaitu untuk lebih membantu memahami materi pembelajaran. Motivasi lainnya yaitu membantu agar dapat diterima di universitas yang diidamkan serta adanya dorongan dari orang tua.
\end{abstract}

Kata Kunci : Motivasi, Bimbingan Belajar, Siswa.

\section{Pendahuluan}

Semakin berkembangnya sistem pendidikan maka semakin berkembangnya pula cara untuk mengikuti sistem pendidikan tersebut, salah satunya berkembangnya Bimbingan Belajar atau yang sering disingkat dengan nama BimBel. Secara keseluruhan, siswa yang mengikuti BimBel didominasi oleh siswa-siswi yang berada di tingkat akhir sekolahnya, seperti kelas XII. Banyak orang tua yang mengharapkan anaknya untuk sukses dalam menggapai cita-citanya, sehingga mencoba untuk membantu dengan cara memotivasi anaknya untuk mengikuti Bimbingan Belajar. 
PSISULA: Prosiding Berkala Psikologi

Vol. 1, 2019

E-ISSN: 2715-002X

Pada dasarnya, tujuan dari siswa-siswi mengikuti BimBel adalah untuk membantu dalam proses belajar, memudahkan siswa dalam memahami materi, meningkatkan prestasinya, dan membantu dalam menggapai cita-citanya. Tetapi, karena adanya dorongan atau motivasi dari orang tua, tujuannya tidak hanya itu, tetapi juga untuk membanggakan orang tua. Apakah dengan adanya permintaan atau dorongan atau pun motivasi dari orang tua untuk mengikuti Bimbingan Belajar, siswa mampu mencapai tujuan-tujuan tersebut dengan baik atau justru tidak sepenuhnya tercapai karena bukan keinginan dari siswa tersebut.

Selain itu, banyak siswa-siswi yang hanya memanfaatkan Bimbingan Belajar yang diikutinya tanpa melakukan belajar mandiri di rumah untuk menunjang kemampuan dan pemahamannya. Mereka hanya akan melakukan belajar mandiri di rumah jika ada hal-hal penting seperti ulangan harian, kuis, dan ujian semester. Hal ini merupakan fenomena yang sejak dulu ada dan dikenal dengan sks atau sistem kebut semalam. Namun ada sebagian besar siswa yang tidak mengikuti Bimbingan Belajar karena beberapa hal, salah satunya yaitu biayanya yang dirasa cukup mahal, padahal siswa memiliki keinginan untuk mengikuti Bimbingan Belajar. Untuk lebih memahami materi dan menggapai cita-citanya, siswa mencoba untuk lebih memanfaatkan intensive class yang diberikan di tiap-tiap sekolah. Dari hal-hal tersebut, apakah siswa-siswi mampu memenuhi harapannya tanpa mengikuti Bimbingan Belajar. Penelitian ini dilakukan untuk mengetahui motivasi dan tujuan siswa-siswi generasi Millenial saat ini untuk mengikuti maupun tidak mengikuti BimBel, kemauan untuk belajar mandiri, dan sejauh mana orang tua berperan menjadi motivasi siswa-siswi tersebut terhadap tujuan yang akan dicapainya nanti.

Terdapat beberapa pendapat mengenai arti motivasi, seperti menurut Uno (2007), motivasi dapat diartikan sebagai dorongan internal dan eksternal dalam diri seseorang yang diindikasikan dengan adanya hasrat dan minat untuk melakukan kegiatan, dorongan dan kebutuhan untuk melakukan kegiatan, harapan dan citacita, penghargaan dan penghormatan atas diri, lingkungan yang baik, serta kegiatan yang menarik. Menurut Vroom (dalam Kreitner \& Kinicki 2007: 247), motivasi adalah mengarahkan dalam memutuskan seberapa besar upaya untuk 
PSISULA: Prosiding Berkala Psikologi

Vol. 1, 2019

E-ISSN: 2715-002X

mengerahkan usaha dalam situasi tertentu. Munandar (2001) mendefinisikan motivasi adalah suatu proses dimana kebutuhan-kebutuhan mendorong seseorang untuk melakukan serangkaian kegiatan yang mengarah ketercapaiannya tujuan tertentu. Individu yang berhasil mencapai tujuannya tersebut maka berarti kebutuhan-kebutuhannya dapat terpenuhi atau terpuaskan.Eyseck, et.al (2013 : 170), mengatakan bahwa sebenarnya motivasi dirumuskan sebagai suatu proses yang menentukan tingkatan kegiatan, intensitas, konsistensi, serta arah umum dari tingkah laku manusia, merupakan konsep yang rumit dan berkaitan dengan konsepkonsep lain, seperti minat, konsep diri, sikap, dan sebagainya.

Dari beberapa penjelasan mengenai motivasi, dapat disimpulkan bahwa motivasi merupakan salah satu faktor yang menekankan diri invidu untuk melakukan suatu usaha tertentu dalam mencapai cita-cita dan harapannya. Tekanan yang dimaksudkan merupakan tekanan yang berasal dari dalam diri individu, seperti minat, cita-cita, dan keinginan, serta dari luar diri individu, seperti orang tua dan lingkungan sekitar, untuk melakukan usaha tertentu dalam mencapai tujuannya.

Pembimbing atau pengajar harus menghadapi tantangan untuk membangkitkan motivasi siswa, membangkitkan minatnya, menarik dan mempertahankan perhatiannya, mengusahakan agar siswa mau mempelajari materi-materi yang diharapkan untuk dipelajarinya (Slameto, 2013 : 173). Hal-hal tersebut dapat dikatan sebagai bimbingan yang dilakukan pembimbing kepada siswa-siswanya. (Slameto, $2013: 2$ ) belajar ialah suatu proses usaha yang dilakukan seseorang untuk memperoleh suatu perubahan tingkah laku yang baru secara keseluruhan, sebagai hasil pengalamannya sendiri dalam interaksi dengan lingkungannya. Bimbingan belajar adalah suatu proses pemberian bantuan dari guru/guru pembimbing kepada siswa dengan cara mengembangkan suasana belajar yang kondusif dan menumbuhkan kemampuan agar siswa terhindar dari dan atau dapat mengatasi kesulitan belajar yang mungkin dihadapinya sehingga mencapai hasil belajar yang optimal (Suherman : 9). Dari beberapa penjelasan di atas, dapat disimpulkan bahwa bimbingan belajar merupakan suatu usaha yang dilakukan 
PSISULA: Prosiding Berkala Psikologi

Vol. 1, 2019

E-ISSN: 2715-002X

dengan bantuan individu lain untuk lebih memahami materi dan mendapatkan perubahan ke arah yang lebih baik sesuai dengan yang diharapkan.

Siswa merupakan pelajar yang duduk di meja belajar setrata sekolah dasar maupun menengah pertama (SMP), serta sekolah menengah ke atas (SMA) (Khuroidah, 2013). RPP Silabus Kurikulum 2013 Revisi (2018) siswa adalah komponen masukan dalam sistem pendidikan, yang selanjutnya diproses dalam proses pendidikan, sehingga menjadi manusia yang berkualitas sesuai dengan tujuan pendidikan nasional. RPP Silabus Kurikulum 2013 Revisi (2018) sebagai suatu komponen pendidikan, siswa dapat ditinjau dari berbagai pendekatan, antara lain : pendekatan sosial, pendekatan psikologis, dan pendekatan edukatif/pedagogis. Dengan demikian, dapat disimpulkan bahwa siswa merupakan bagian dari unsur pendidikan yang akan mengalami perubahan ke arah yang lebih baik, yang berada di tingkat dasar (SD), menengah (SMP), maupun atas (SMA).

\section{Metode}

Penelitian ini menggunakan metode deskriptif dengan teknik pengumpulan data melalui google form maupun pengisian langsung. Teknik ini dilakukan dengan tujuan untuk menjelaskan motivasi siswa-siswi memilih untuk mengikuti maupun tidak mengikuti Bimbingan Belajar, keterkaitan orang tua dengan motivasi anak dalam mengikuti Bimbingan Belajar, dan perekonomiannya, dilihat dari pekerjaan orang tua. Penelitian ini melibatkan siswa-siswi kelas XII yang berusia 17 tahun di Purwokerto. Penelitian ini dilakukan sejak Agustus hingga September 2019.

Penelitian survei diarahkan untuk mengetahui dan mempelajari data dari sampel yang diambil dari populasi, sehingga ditemukan kejadian-kejadian relatif, distribusi, serta hubungan-hubungan antar variabel. Penelitian survei dapat dilakukan pada populasi kecil maupun besar (Kurniawan Widhi, et al. 2016).

\section{Hasil}

Penelitian ini dilakukan di Purwokerto dengan subyek penelitian adalah siswa-siswi kelas XII yang berusia 17 tahun dengan jumlah 12 orang. Penelitian ini 
PSISULA: Prosiding Berkala Psikologi

Vol. 1, 2019

E-ISSN: 2715-002X

dilakukan pada rentan waktu satu bulan, yaitu pada bulan Agustus hingga September 2019.

\section{a. Dorongan dari orang tua}

Dari hasil penelitian menunjukkan adanya keseimbangan antara iya atau tidak, terkait dorongan atau motivasi orang tua untuk mengikuti bimbingan belajar.

Motivasi Mengikuti Bimbingan Belajar

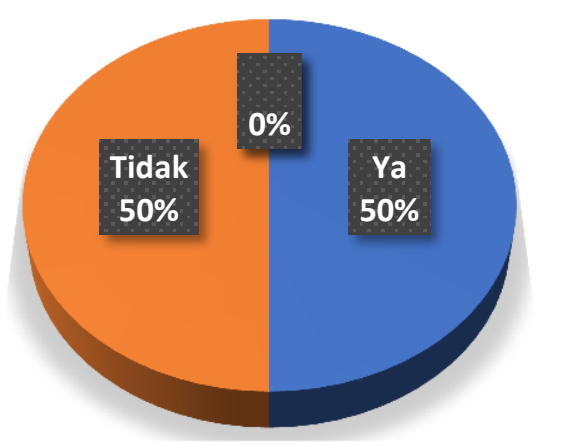

$\square \mathrm{Ya}$

- Tidak

Gambar 1. Diagram Prosentase Motivasi Mengikuti Bimbingan Belajar

\section{Keinginan untuk lebih memahami materi}

Seluruh siswa menunjukkan hasil memiliki motivasi mengikuti Bimbingan Belajar untuk lebih memahami materi yang diterima di sekolahnya. Hal ini didukung dengan adanya intensitas belajar mandiri yang dilakukan di rumah.

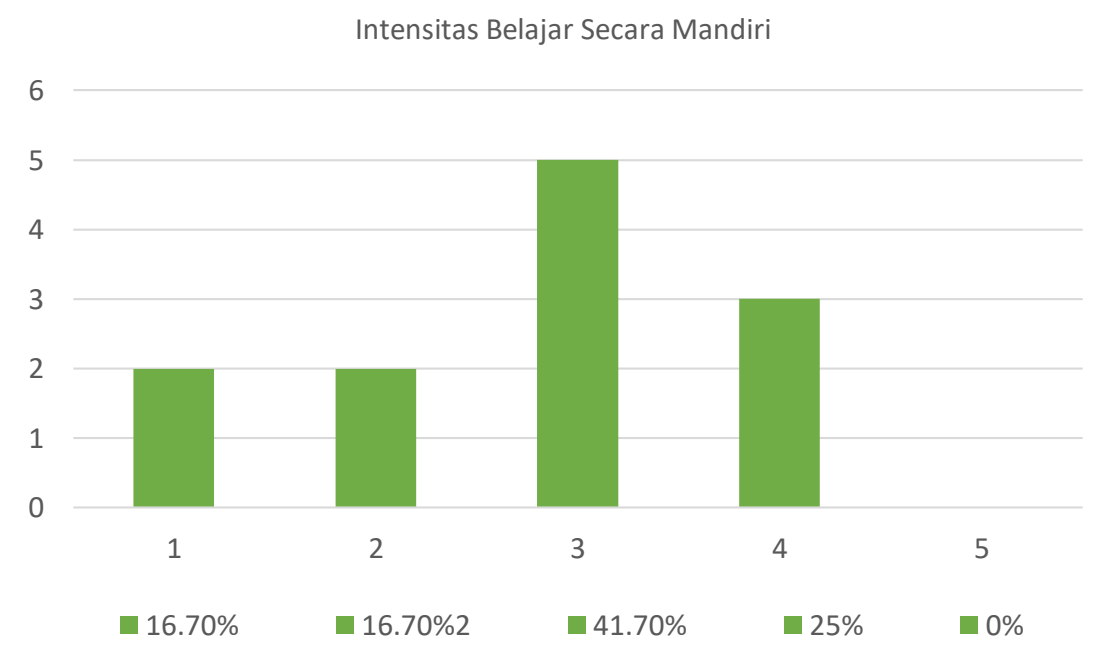

Gambar 2. Grafik Insentitas Belajar Secara Mandiri 
PSISULA: Prosiding Berkala Psikologi

Vol. 1, 2019

E-ISSN: 2715-002X

\section{b. Untuk membantu dalam menggapai cita-cita}

Adanya cita-cita yang ingin dicapai, membuat siswa memiliki motivasi untuk mengikuti Bimbingan Belajar.

Dengan ciri-ciri responden pada penelitian ini, siswa kelas XII yang berumur 17 tahun serta jumlah responden laki-laki 3 dan perempuan 9, diketahui memiliki beberapa motivasi dalam mengikuti Bimbingan Belajar atau BimBel sesuai dengan yang sudah dijelaskan di atas, yaitu (a) adanya dorongan dari orang tua, (b) adanya keinginan untuk lebih memahami materi yang sudah disampaikan di sekolah. Hal ini didukung dengan adanya kemauan belajar secara mandiri di rumah dengan intensitas yang sedang hingga lebih, dan (c) adanya cita-cita yang ingin dicapai.

\section{Diskusi}

Berdasarkan hasil penelitian yang telah dilakukan, diketahui bahwa ada beberapa faktor yang memotivasi siswa-siswi untuk mengikuti Bimbingan Belajar, yaitu : (a) adanya dorongan dari orang tua, (b) adanya keinginan untuk lebih memahami materi yang sudah disampaikan di sekolah. Hal ini didukung dengan adanya intensitas belajar mandiri di rumah, dan (c) adanya cita-cita yang ingin dicapai. Sehingga dari hasil tersebut, dapat membuktikan bahwa hipotesis yang menyatakan motivasi siswa untuk mengikuti BimBel yaitu untuk lebih membantu memahami materi pembelajaran. Motivasi lainnya yaitu membantu agar dapat diterima di universitas yang diidamkan serta adanya dorongan dari orang tua, dapat diterima.

Menurut Vroom (dalam Kreitner \& Kinicki 2007 : 247), motivasi adalah mengarahkan dalam memutuskan seberapa besar upaya untuk mengerahkan usaha dalam situasi tertentu. Pembimbing atau pengajar harus menghadapi tantangan untuk membangkitkan motivasi siswa, membangkitkan minatnya, menarik dan mempertahankan perhatiannya, mengusahakan agar siswa mau mempelajari materi-materi yang diharapkan untuk dipelajarinya (Slameto, 2013 : 173). Hal-hal tersebut dapat dikatan sebagai bimbingan yang dilakukan pembimbing kepada 
PSISULA: Prosiding Berkala Psikologi

Vol. 1, 2019

E-ISSN: 2715-002X

siswa-siswanya. Dalam RPP Silabus Kurikulum 2013 Revisi (2018) siswa adalah komponen masukan dalam sistem pendidikan, yang selanjutnya diproses dalam proses pendidikan, sehingga menjadi manusia yang berkualitas sesuai dengan tujuan pendidikan nasional.

\section{Kesimpulan}

Dari penjelasan di atas, dapat disimpulkan bahwa terdapat beberapa motivasi siswa untuk mengikuti Bimbingan Belajar, yaitu adanya dorongan dari orang tua, kemauan untuk lebih memahami materi yang didapat di sekolah, dan menggapai cita-cita yang diharapkan.

\section{Daftar Pustaka}

Isnaini, J. (2013). Pengambilan keputusan menikah muda. (Skripsi, Tidak Dipublikasikan). Universitas Islam Negeri Maulana Malik Ibrahim.

Muhdi, Kastawi, N., \& Widodo, S. (2017). Teknik Pengambilan Keputusan dalam Menentukan Model Manajemen Pendidikan Menengah. Kelola : Jurnal Manajemen Pendidikan, 4 (2), 135-145.

Rangga, M., \& Naomi, P. (2007). Pengaruh Motivasi Diri Terhadap Kinerja Belajar Mahasiswa (Studi Kasus Pada Mahasiswa Universitas Paramadina). Jurnal UPI, 1-8.

RPP Silabus Kurikulum 2013 Revisi 2018, Abad 21.www.rpp-silabus.com(di akses 15 September 2019).

Setiawan Cahaya, K. (2015). Pengaruh Motivasi Kerja Terhadap Kinerja Karyawan Level Pelaksana di Divisi Operasi PT. Pusri Palembang. Jurnal Psikologi Islam, 1(2), 43-55.

Slameto.(2013). Belajar dan Faktor-Faktor yang Mempengaruhi. Jakarta : Rineka Cipta.

Suherman.Bimbingan Belajar. Diakses dari http://file.upi.edu/Direktori/FIP/JUR._PSIKOLOGI_PEND_DAN_BIMBINGAN/1 95903311986031-SUHERMAN/Bimbingan_Belajar.pdf

Thahir, A., \& Hidriyanti, B. (2014).Pengaruh Bimbingan Belajar Terhadap Prestasi Belajar Siswa Pondok Pesantren Madrasah Aliyah Al-Utrujiyyah Kota Karang.Jurnal Bimbingan dan Konseling, 1 (2), 63-76. 